\title{
Public knowledge and attitudes towards cardiopulmonary resuscitation in Hong Kong: telephone survey
}

\author{
SY Chair, Maria SY Hung *, Joseph CZ Lui, Diana TF Lee, Irene YC Shiu, KC Choi
}

\section{A B S T R A C T}

Objectives: To investigate the public's knowledge and attitudes about cardiopulmonary resuscitation in Hong Kong.

Design: Cross-sectional telephone survey.

Setting: Hong Kong.

Participants: Hong Kong residents aged 15 to 64 years.

Main outcome measures: The knowledge and attitudes towards cardiopulmonary resuscitation.

Results: Among the 1013 respondents, only 214 (21\%) reported that they had received cardiopulmonary resuscitation training. The majority $(72 \%)$ of these trained respondents had had their latest training more than 2 years earlier. The main reasons for not being involved in cardiopulmonary resuscitation training included lack of time or interest, and "not necessary". People with full-time jobs and higher levels of education were more likely to have such training. Respondents stating they had received cardiopulmonary resuscitation training were more willing to try it if needed at home (odds ratio $=3.3$; 95\% confidence interval, 2.4-4.6; $\mathrm{P}<0.001)$ and on strangers in the street $(4.3 ; 3.1-6.1 ; \mathrm{P}<0.001)$ in case of emergencies. Overall cardiopulmonary resuscitation
This article was published on $14 \mathrm{Mar}$ 2014 at www.hkmj.org. them $(0.4 \%)$ answered all the questions correctly.

Conclusions: Knowledge of cardiopulmonary resuscitation was still poor among the public in Hong Kong and the percentage of population trained to perform it was also relatively low. Efforts are needed to promote educational activities and explore other approaches to skill reinforcement and refreshment. Besides, we suggest enacting laws to protect bystanders who offer cardiopulmonary resuscitation, and incorporation of relevant training course into secondary school and college curricula.

\begin{tabular}{l} 
Hong Kong Med J 2014;20:126-33 \\
\hline DOI: 10.12809/hkmj134076 \\
${ }^{1}$ SY Chair, PhD \\
${ }^{2}$ MSY Hung *, DHSc, MN \\
${ }^{3}$ JCZ Lui, FHKCA, FHKAM (Anaesthesiology) \\
${ }^{1}$ DTF Lee, PhD \\
${ }^{4}$ IYC Shiu, MHA, MNurs (AdvPrac) \\
${ }^{1}$ KC Choi, PhD \\
${ }^{1}$ The Nethersole School of Nursing, The Chinese University of Hong \\
Kong, Shatin, Hong Kong \\
${ }^{2}$ School of Nursing, The Hong Kong Polytechnic University, Hunghom, \\
Hong Kong \\
${ }^{3}$ United Christian Hospital, Hospital Authority, Hong Kong \\
${ }^{4}$ Resuscitation Training Centre, Caritas Medical Centre, Shamshuipo, \\
Hong Kong \\
* Corresponding author: maria.hung@polyu.edu.hk
\end{tabular}

New knowledge added by this study

- Knowledge of cardiopulmonary resuscitation (CPR) is still poor among members of the Hong Kong public, and a relatively low percentage of the population has received relevant training.

Implications for clinical practice or policy

- The Hong Kong government and non-government organisations need to promote educational activities and explore other approaches to reinforce and refresh participation in CPR.

- There is a need to enact laws to increase public awareness of CPR and protect bystanders who perform it.

- Incorporating CPR training into the secondary schools and colleges as part of a general education course is warranted.

\section{Introduction}

Out-of-hospital cardiac arrest is a public health problem and leads to the highest proportion of deaths in many parts of the world. ${ }^{1,2}$ According to the American Heart Association (AHA), in the US and Canada, approximately 350000 people per year suffer out-of-hospital cardiac arrests for which cardiopulmonary resuscitation (CPR) is attempted. ${ }^{1,3,4}$ In Hong Kong, although no such direct epidemiological information can be referred to, more than 1000 persons are believed to die suddenly and unexpectedly each year; many of which are presumed to be primarily due to cardiac arrests. ${ }^{5}$

For those who endure sudden cardiac arrests, early, high-quality CPR can greatly improve chances of survival. ${ }^{6,7}$ Nowadays, the importance of CPR is well recognised and emphasised. Accordingly, the AHA even recommended that CPR training and familiarisation with automated external defibrillators (AEDs) should be included in secondary school 
curricula. ${ }^{8}$ Thus, equipping the public with such skills becomes one of the essential strategies to increase the success of CPR for cardiac arrest victims.

In recent years, studies have been conducted to examine the knowledge and attitude of the public regarding CPR. In general, people had poor knowledge on this subject and the proportion of the public who had received the CPR training was low. ${ }^{9-12}$ Besides, many individuals did not want to perform cardiac compression with mouth-to-mouth ventilation, due to fear of acquiring transmitted diseases. ${ }^{13}$ These factors are likely to limit the numbers of bystander CPRs carried out and contribute to the low survival rates from out-of-hospital cardiac arrests. A local study showed that for out-of-hospital cardiac arrests, the frequency of bystander CPR was only about $15.7 \%$ and the survival rate to eventual discharge from hospital was as low as $1.3 \%$ in Hong Kong. ${ }^{10}$

To identify effective measures to promote CPR, the current situation should be evaluated. This study aimed to explore the Hong Kong public's knowledge and attitudes about CPR. Its findings could inform the community regarding preferences to perform bystander CPR and more importantly it could indicate directions for future training.

\section{Methods}

\section{Population and data collection}

This was a cross-sectional population-based survey. The study population comprised the Chinese Hong Kong residents aged 15 to 64 years, who speak Cantonese in domestic households. Anonymous telephone interviews using a structured questionnaire were conducted and launched in the Telephone Survey Research Laboratory of the Hong Kong Institute of Asia-Pacific Studies of The Chinese University of Hong Kong. By using the Computer Assisted Telephone Interviewing system, telephone numbers were randomly selected from up-to-date residential telephone directories that covered over 95\% of Hong Kong households. The interviews were conducted between 6:15 pm and 10:15 pm, to avoid over-representing the non-working population. For households with more than one eligible member, the one whose birthday was closest to the interview date was invited to join the study. At least three attempts were made to contact individuals in any given household. Such attempts were made at different times of the day and/or different days of the week, to avoid being labelled a non-contact status (with an assigned number) so as to ensure that survey results were not biased due to high noncontact/non-response rates. Eligible respondents were briefed about the study and verbal consent was sought. The study was approved by the Survey and Behavioural Research Ethics Committee of The Chinese University of Hong Kong.

\section{香港市民對心肺復蘇法的知識和態度：電話訪談}

車錫英、熊淑茹、雷操媔、李子芬、蕭玉珍、蔡繼洲

目的：調查香港市民對心肺復蘇法的知識和態度。

設計：橫斷面電話訪談。

安排：香港。

參與者：年齡介乎 15 至64歲的香港市民。

主要結果測量：香港市民對心肺復蘇法的知識和態度。

結果：在1013名受訪者中, 只有 214 人（21\%）曾接受心肺復蘇法 的訓練。大部分 $(72 \%)$ 曾接受訓練的受訪者, 其上一次的培訓已 是兩年前。沒有接受心肺復蘇法訓練的主要原因包括缺乏時間或興 趣, 及「沒有必要」。全職工作和教育水平較高的人較多有接受 心肺復蘇法的訓練。在緊急情況時, 曾接受心肺復蘇訓練的受訪 者會願意在家中為家人（比數比 $=3.3 ； 95 \%$ 置信區間：2.4-4.6； $\mathrm{P}<0.001$ ) 或在街上為陌生人（比數比 $=4.3 ； 95 \%$ 置信區間：3.1$6.1 ; \mathrm{P}<0.001)$ 嘗試進行心肺復蘇法。受訪者心肺復蘇法的知識總 分數偏低（中位數 $=1$; 最高分數為 8 ）。在所有受訪者中, 只有 4 人 $(0.4 \%)$ 能正確回答所有項目

結論：香港市民對心肺復蘇法的知識仍然貧乏，曾接受心肺復蘇法訓 練的比率相對較低。須積極推行普及教育活動, 並探索鞏固和更新心 肺復蘇法技能的其他方法。同時, 亦應從法律角度保護在院外進行心 肺復蘇法的人, 亦建議將心肺復蘇培訓納入中學和大學的通識教育課 程中。

\section{Sample size}

According to a previous study, ${ }^{11} 12 \%$ of the population had received CPR training. Owing to continuing efforts and CPR promotion programmes/campaigns by different associations and organisations in recent years, it was expected that around $20 \%$ of the study population had probably received prior CPR training. Depending on the possible prevalence of subjects with prior CPR training (ranging from 18 to $22 \%$ ), it was estimated that 883 to 1025 subjects would be sufficient to estimate knowledge and attitudes with a margin of error of $\pm 2.5 \%$ at $5 \%$ level of significance. The sample size calculation was performed using PASS 11 (NCSS, Kaysville [UT], US). Thus, we aimed to recruit over 1000 subjects for this study.

\section{Questionnaire}

In this study we used a structured questionnaire, which took about 5 to 10 minutes to complete, and was developed in January 2010 (Appendix). It was based on the 2005 AHA Guidelines for CPR and Emergency Cardiovascular Care, ${ }^{14}$ Basic Life Support for health care providers, ${ }^{15}$ and a review of the relevant literature. ${ }^{11,12}$ It consisted of three sections. The first entailed questions on demographics, including age, gender, education level, occupation, family history of heart disease, and ischaemic heart disease risk factors. The second entailed questions about previous CPR training. The 
third entailed questions on attitudes and knowledge regarding CPR. To evaluate respondents' relevant attitudes and knowledge, questions were included about: willingness to perform CPR ( 2 items), the basic knowledge related to a victim's response (1 item), management of airway ( 2 items), breathing ( 2 items), circulation ( 2 items), and AED usage ( 1 item). The anticipated answers for the CPR knowledge questions (victim's response, management of airway, breathing, and circulation) were consistent with information in the latest AHA guidelines (2005 version). Content validity was established by an expert panel including four doctors and six nurses who were either AHA Basic Life Support providers or instructors. The content validity index rating item's relevance to the underlying construct was 0.96.

\section{Statistical analyses}

Data were categorised and presented in frequencies (percentages). Univariate comparisons on demographics and ischaemic heart disease risk factors among those with and without CPR training were conducted, using Pearson Chi squared or Fisher's exact tests, as appropriate. Logistic regression analysis was used to identify demographics and ischaemic heart disease risk factors (Table 1) that were associated with CPR training. Variables with a $\mathrm{P}$ value of $<0.25$ in the univariate analysis were selected for use in the stepwise multivariate logistic regression analysis, to delineate factors independently associated with CPR training. ${ }^{16}$

Logistic regression models were also employed to compare subjects with and without CPR training with respect to various outcome variables (attitude and knowledge about CPR), after adjustment for demographics and coronary heart disease risk factors. A 'two-block stepwise' logistic regression modelling approach was used to make adjusted comparisons of the two groups. The grouping factor (CPR training: Yes/No) was first entered into logistic regression model and then the demographics and ischaemic heart disease risk factors (Table 1) were entered in another block with stepwise selection. In the final model, the adjusted odds ratio (OR) to compare those with and without CPR training (reference group) was derived, taking account of demographics and ischaemic heart disease risk factors. All statistical analyses were conducted using SPSS 19.0 (Windows version 19.0; SPSS Inc, Chicago [IL], US) with two-sided tests; a P value of $<0.05$ was considered statistically significant.

\section{Results}

In this study, 2703 phone calls were not picked up after three attempts, and 5669 calls were picked up but 2735 calls were disconnected immediately after knowing the purpose of the calls. A total of
2188 eligible respondents were identified, 1175 refused to participate. Finally, 1013 interviews were conducted (response rate, 46\%). The demographics and ischaemic heart disease risk factors of these respondents are shown in Table 1.

\section{Cardiopulmonary resuscitation training characteristics}

Among the 1013 respondents, only 214 (21\%) reported that they had received CPR training; the majority $(72 \%, n=154)$ of whom had had their latest training more than 2 years earlier. A large proportion $(63 \%, n=134)$ of the trained respondents received their training via the Hong Kong St John Ambulance $(49 \%, \mathrm{n}=104)$ and the Hong Kong Red Cross $(14 \%, n=30)$. Another $35(16 \%)$ participants had their training via their companies or workplaces. Their main reasons for taking CPR training were 'job requirement' $(48 \%, \mathrm{n}=102)$ and 'personal interest' $(42 \%, n=90)$. For those who did not take CPR training $(n=799)$, most of them $(74 \%, n=589)$ claimed that they would not consider participating in CPR training in the future. Reasons for not taking CPR training could be multiple, and included 'no time' $(41 \%, n=241)$, 'not necessary' $(26 \%, n=156)$, and 'not interested' (19\%, $\mathrm{n}=110)$. In addition, $104(18 \%)$ participants picked 'unable to learn CPR because of their low education level or being too old?

\section{Factors associated with having cardiopulmonary resuscitation training}

Demographic and ischaemic heart disease risk factors listed in Table 1 with a $P$ value of $<0.25$ in the univariate analysis were selected as candidate variables for multivariate stepwise logistic regression. ${ }^{16}$ Among them, age, education level, full-time working status, occupation, having dyslipidaemia and hypertension were associated with having CPR training in the univariate analysis. However, only having a fulltime job $(\mathrm{OR}=2.2 ; 95 \%$ confidence interval $[\mathrm{CI}]$, 1.6-3.1; $\mathrm{P}<0.001)$, middle level education-Form 4-7/technical institute $(\mathrm{OR}=2.3$; 95\% CI, 1.5-3.6; $\mathrm{P}<0.001)$, and a high level of education-college or higher $(\mathrm{OR}=2.7 ; 95 \% \mathrm{CI}, 1.7-4.2 ; \mathrm{P}<0.001)$, were significantly associated with having CPR training in the multivariate analysis. Notably, having a low education level-Form 3 or below-was not significantly associated with such training (Table 2).

\section{Willingness to perform cardiopulmonary resuscitation}

As shown in Table 3, the ratio of respondents with and without training willing to attempt CPR on family members at home was $72 \%$ vs $45 \%(P<0.001)$ and on strangers in the street was $42 \%$ vs $15 \%(P<0.001)$. Logistic regression analysis revealed that after adjusting for potentially confounding demographic and ischaemic heart disease risk factors, those with 
TABLE I. Demographics and coronary risk characteristics of the respondents $(n=1013)$

\begin{tabular}{|c|c|c|c|c|}
\hline \multirow[t]{2}{*}{ Characteristic } & \multicolumn{3}{|c|}{ No. (\%) of respondents } & \multirow[t]{2}{*}{ P value* } \\
\hline & All $(n=1013)$ & Without training $(n=799)$ & With CPR training $(n=214)$ & \\
\hline \multicolumn{5}{|l|}{ Demographic characteristics } \\
\hline \multicolumn{5}{|l|}{ Age (years) } \\
\hline$<30$ & $244(24)$ & $195(24)$ & $49(23)$ & $<0.001$ \\
\hline $30-49$ & $373(37)$ & $271(34)$ & $102(48)$ & \\
\hline$\geq 50$ & $396(39)$ & $333(42)$ & $63(29)$ & \\
\hline \multicolumn{5}{|l|}{ Sex } \\
\hline Male & $440(43)$ & $349(44)$ & $91(43)$ & 0.762 \\
\hline Female & $573(57)$ & $450(56)$ & $123(57)$ & \\
\hline \multicolumn{5}{|l|}{ Education levelł } \\
\hline Form 3 or below & $310(31)$ & $277(35)$ & $33(15)$ & $<0.001$ \\
\hline Form 4-7 or technical institute & $400(39)$ & $305(38)$ & $95(44)$ & \\
\hline College or above & $300(30)$ & $214(27)$ & $86(40)$ & \\
\hline \multicolumn{5}{|l|}{ Full-time working } \\
\hline No & $505(50)$ & $437(55)$ & $68(32)$ & $<0.001$ \\
\hline Yes & $508(50)$ & $362(45)$ & $146(68)$ & \\
\hline \multicolumn{5}{|l|}{ Occupation } \\
\hline Manager / administrator / professional & $90(9)$ & $63(8)$ & $27(13)$ & $<0.001$ \\
\hline Associate professional / clerk & $189(19)$ & $126(16)$ & $63(29)$ & \\
\hline Service worker and shop sales worker & $83(8)$ & $59(7)$ & $24(11)$ & \\
\hline Technician / skilled worker & $70(7)$ & $54(7)$ & $16(7)$ & \\
\hline Non-skilled worker & $56(6)$ & $45(6)$ & $11(5)$ & \\
\hline Housewife & $157(15)$ & $141(18)$ & $16(7)$ & \\
\hline Student & $143(14)$ & $116(15)$ & $27(13)$ & \\
\hline Retired & $118(12)$ & $104(13)$ & $14(7)$ & \\
\hline Unemployed & $45(4)$ & $38(5)$ & $7(3)$ & \\
\hline Others & $62(6)$ & $53(7)$ & $9(4)$ & \\
\hline \multicolumn{5}{|l|}{ Coronary risk characteristics } \\
\hline \multicolumn{5}{|l|}{ Dyslipidaemia } \\
\hline No & $702(69)$ & $537(67)$ & $165(77)$ & 0.020 \\
\hline Yes & $172(17)$ & $146(18)$ & $26(12)$ & \\
\hline Unsure & $139(14)$ & $116(15)$ & $23(11)$ & \\
\hline \multicolumn{5}{|l|}{ Hypertension } \\
\hline No & $800(79)$ & $617(77)$ & $183(86)$ & 0.029 \\
\hline Yes & $146(14)$ & $124(16)$ & $22(10)$ & \\
\hline Unsure & $67(7)$ & $58(7)$ & $9(4)$ & \\
\hline \multicolumn{5}{|l|}{ Diabetes } \\
\hline No & $897(89)$ & $702(88)$ & $195(91)$ & $0.408+$ \\
\hline Yes & $59(6)$ & $49(6)$ & $10(5)$ & \\
\hline Unsure & $57(6)$ & $48(6)$ & $9(4)$ & \\
\hline \multicolumn{5}{|l|}{ Confirmed heart disease } \\
\hline No & $996(98)$ & $786(98)$ & $210(98)$ & 0.767 \\
\hline Yes & $17(2)$ & $13(2)$ & $4(2)$ & \\
\hline \multicolumn{5}{|l|}{ Family history of heart disease } \\
\hline No & $806(80)$ & $630(79)$ & $176(82)$ & 0.287 \\
\hline Yes & $178(18)$ & $143(18)$ & $35(16)$ & \\
\hline Unsure & $29(3)$ & $26(3)$ & $3(1)$ & \\
\hline \multicolumn{5}{|l|}{ Current smoker } \\
\hline No & $931(92)$ & $732(92)$ & $199(93)$ & 0.512 \\
\hline Yes & $82(8)$ & $67(8)$ & $15(7)$ & \\
\hline
\end{tabular}

Abbreviation: CPR = cardiopulmonary resuscitation

* All P values between the two groups were obtained using Pearson Chi squared test, except those marked with $†$ that were derived using Fisher's exact test

$\neq$ Data of three respondents in the without-training group are missing because they refused to provide the information 
CPR training were also more likely to attempt CPR of the eight knowledge questions (all $\mathrm{P}<0.001)$. After at home $(\mathrm{OR}=3.3 ; 95 \% \mathrm{CI}, 2.4-4.6 ; \mathrm{P}<0.001)$ and adjusting for potential confounding demographic in the street $(\mathrm{OR}=4.3 ; 95 \% \mathrm{CI}, 3.1-6.1 ; \mathrm{P}<0.001)$ in and ischaemic heart disease risk factors, logistic emergencies (Table 3).

\section{Knowledge on cardiopulmonary resuscitation} regression showed that the trained group was significantly more likely to give five or more appropriate responses to the eight knowledge items when compared with those without such Regarding knowledge on CPR, trained respondents training ( $\mathrm{OR}=19.8 ; 95 \% \mathrm{CI}, 11.4-34.4 ; \mathrm{P}<0.001$; were more likely to give correct responses to each Table 3). Although the trained respondents achieved

TABLE 2. Demographics and coronary risk characteristics associated with CPR training

\begin{tabular}{|c|c|c|c|c|c|c|}
\hline \multirow[t]{2}{*}{ Characteristic } & \multicolumn{2}{|c|}{ CPR training, No. (\%) } & \multirow[t]{2}{*}{$\mathrm{OR}_{\mathrm{u}}$} & \multirow[t]{2}{*}{$P$ value } & \multirow[t]{2}{*}{$\mathrm{OR}_{\mathrm{A}}(95 \% \mathrm{Cl}) \dagger$} & \multirow[t]{2}{*}{$P$ value } \\
\hline & $\begin{array}{c}\text { Without training } \\
(n=799)\end{array}$ & $\begin{array}{l}\text { With CPR training } \\
(n=214)\end{array}$ & & & & \\
\hline \multicolumn{7}{|l|}{ Demographic characteristics } \\
\hline \multicolumn{7}{|l|}{ Age (years) } \\
\hline$<30^{*}$ & $195(80)$ & $49(20)$ & 1 & & NS§ & \\
\hline $30-49$ & $271(73)$ & $102(27)$ & 1.50 & 0.041 & & \\
\hline$\geq 50$ & $333(84)$ & $63(16)$ & 0.75 & 0.178 & & \\
\hline \multicolumn{7}{|l|}{ Sex } \\
\hline Male $^{*}$ & $349(79)$ & $91(21)$ & 1 & & NE\|l & \\
\hline Female & $450(79)$ & $123(21)$ & 1.05 & 0.762 & & \\
\hline \multicolumn{7}{|l|}{ Education levelł } \\
\hline Form 3 or below* & 277 (89) & $33(11)$ & 1 & & 1 & \\
\hline Form 4-7/technical institute & $305(76)$ & $95(24)$ & 2.62 & $<0.001$ & $2.3(1.5-3.6)$ & $<0.001$ \\
\hline College or above & $214(71)$ & $86(29)$ & 3.37 & $<0.001$ & $2.7(1.7-4.2)$ & $<0.001$ \\
\hline \multicolumn{7}{|l|}{ Full-time working } \\
\hline $\mathrm{No}^{*}$ & $437(87)$ & $68(13)$ & 1 & & 1 & \\
\hline Yes & $362(71)$ & $146(29)$ & 2.59 & $<0.001$ & $2.2(1.6-3.1)$ & $<0.001$ \\
\hline \multicolumn{7}{|l|}{ Coronary risk characteristics } \\
\hline \multicolumn{7}{|l|}{ Dyslipidaemia } \\
\hline No / unsure* & $653(78)$ & $188(22)$ & 1 & & NS & \\
\hline Yes & $146(85)$ & $26(15)$ & 0.62 & 0.035 & & \\
\hline \multicolumn{7}{|l|}{ Hypertension } \\
\hline No / unsure* & $675(78)$ & $192(22)$ & 1 & & NS & \\
\hline Yes & $124(85)$ & $22(15)$ & 0.62 & 0.054 & & \\
\hline \multicolumn{7}{|l|}{ Diabetes } \\
\hline No / unsure* & $750(79)$ & $204(21)$ & 1 & & NE & \\
\hline Yes & $49(83)$ & $10(17)$ & 0.75 & 0.420 & & \\
\hline \multicolumn{7}{|l|}{ Confirmed heart disease } \\
\hline $\mathrm{No}^{*}$ & $786(79)$ & $210(21)$ & 1 & & NE & \\
\hline Yes & $13(76)$ & $4(24)$ & 1.15 & 0.807 & & \\
\hline \multicolumn{7}{|l|}{ Family history of heart disease } \\
\hline No / unsure* & $656(79)$ & $179(21)$ & 1 & & NE & \\
\hline Yes & $143(80)$ & $35(20)$ & 0.90 & 0.599 & & \\
\hline \multicolumn{7}{|l|}{ Current smoker } \\
\hline No / unsure* & $732(79)$ & $199(21)$ & 1 & & NE & \\
\hline Yes & 67 (82) & $15(18)$ & 0.82 & 0.513 & & \\
\hline
\end{tabular}

Abbreviations: $\mathrm{Cl}=$ confidence interval; $\mathrm{CPR}=$ cardiopulmonary resuscitation; $\mathrm{OR}_{\mathrm{A}}=$ adjusted odds ratio; $\mathrm{OR}_{\mathrm{u}}=$ univariate odds ratio

* Reference group of the categorical variable that analysed by creating dummy variables

$+\mathrm{OR}_{\mathrm{A}}$ : odds ratio adjusted for other significant factors obtained from stepwise logistic regression analysis using variables with $\mathrm{P}<0.25$ in univariate analysis as candidate variables

₹ Data of three respondents in the without-training group are missing because they refused to provide the information

$\S$ NS: not statistically significant in multivariate analysis

॥ NE: $P \geq 0.25$ in univariate analysis and hence not entered into multivariate analysis 
TABLE 3. Logistic regression models for the comparison of willingness to perform CPR and knowledge about CPR between those with and without CPR training

\begin{tabular}{|c|c|c|c|c|c|c|}
\hline \multirow[t]{2}{*}{ Outcome variable } & \multicolumn{2}{|c|}{ CPR training, No. (\%) } & \multicolumn{2}{|c|}{ Unadjusted model } & \multicolumn{2}{|c|}{ Adjusted model } \\
\hline & No $(n=799)$ & Yes $(n=214)$ & $\mathrm{OR}_{\mathrm{u}}(95 \% \mathrm{Cl})^{\star}$ & $P$ value & $\mathrm{OR}_{\mathrm{A}}(95 \% \mathrm{Cl}) \dagger$ & $P$ value \\
\hline \multicolumn{7}{|c|}{ Attitude (willingness to perform CPR) } \\
\hline \multicolumn{7}{|c|}{$\begin{array}{l}\text { If your family member is found unconscious / } \\
\text { unresponsive at home, will you perform CPR when } \\
\text { the ambulance is not yet arrived? }\end{array}$} \\
\hline No / unsure & $440(55)$ & $59(28)$ & 1 & & 1 & \\
\hline Yes & $359(45)$ & $155(72)$ & $3.2(2.3-4.5)$ & $<0.001$ & $3.3(2.4-4.6)$ & $<0.001$ \\
\hline \multicolumn{7}{|c|}{$\begin{array}{l}\text { If somebody is found unconscious / unresponsive } \\
\text { in the street, will you perform CPR when the } \\
\text { ambulance is not yet arrived? }\end{array}$} \\
\hline No / unsure & $682(85)$ & $125(58)$ & 1 & & 1 & \\
\hline Yes & $117(15)$ & $89(42)$ & $4.2(3.0-6.4)$ & $<0.001$ & $4.3(3.1-6.1)$ & $<0.001$ \\
\hline \multicolumn{7}{|c|}{ Knowledge about CPR } \\
\hline \multicolumn{7}{|c|}{$\begin{array}{l}\text { No. of appropriate responses to } 8 \text { CPR-related } \\
\text { knowledge items }\end{array}$} \\
\hline $0-4$ & $781(98)$ & $147(69)$ & 1 & & 1 & \\
\hline $5-8$ & $18(2)$ & $67(31)$ & 19.8 (11.4-34.3) & $<0.001$ & 19.8 (11.4-34.4) & $<0.001$ \\
\hline \multicolumn{7}{|c|}{$\begin{array}{l}\text { Abbreviations: } \mathrm{Cl}=\text { confidence interval; } \mathrm{CPR}=\text { cardiopulmonary resuscitation; } \mathrm{OR}_{\mathrm{A}}=\text { adjusted odds ratio; } \mathrm{OR}=\mathrm{U} \text { univariate odds ratio } \\
\text { * } \mathrm{OR} \text { : unadjusted odds ratio of CPR-training group compared with without-CPR-training group (reference group) obtained by logistic regression } \\
+\mathrm{OR}_{\mathrm{A}} \text { : adjusted odds ratio of CPR-training group compared with without-CPR-training group (reference group) obtained by 2-block stepwise logistic } \\
\text { regression with adjustment for potential confounding demographics and coronary risk factors: age, gender, education level, full-time working status, status } \\
\text { of dyslipidaemia, hypertension, diabetes, heart disease, family history of heart disease, and smoking }\end{array}$} \\
\hline
\end{tabular}

higher scores on CPR knowledge (median=3) than those who were untrained (median $=1$ ), the overall CPR knowledge level of the respondents was low (median=1). Among all the 1013 respondents, only four $(0.4 \%)$ answered all the questions correctly (score $=8$ ), which also represented $1.9 \%$ of those who had received CPR training (Table 4).

\section{Discussion}

The present study showed that $21 \%$ of the respondents had received CPR training, which was higher than in a previous local study reporting $12 \% .{ }^{11}$ Our rate was comparable to data reported from elsewhere (27\% in New Zealand and $28 \%$ in Ireland), ${ }^{17,18}$ but much lower than in reports from Australia (58\%), ${ }^{19}$ Poland (75\%), ${ }^{20}$ and Washington $(79 \%) .{ }^{21}$ Therefore, though the trend for CPR training in Hong Kong seems to be increasing, it seems far from sufficient, and the majority had received their training more than 2 years earlier. Although it is commonly believed that performing CPR without $100 \%$ accuracy is better than doing nothing, whether our respondents could perform appropriate CPR in an emergency was questionable. In our cohort, skills appeared to have deteriorated with time. One study suggested that 6 -monthly reinstruction was needed to maintain adequate CPR skills ${ }^{22}$; the 2-year intervals noted in this study were much longer than what has been suggested. Thus, after their first training, it is suggested that individuals should attend refresher courses. Moreover, the training institutions should
TABLE 4. Appropriate response to knowledge about CPR

\begin{tabular}{lccc}
\hline $\begin{array}{l}\text { No. of appropriate } \\
\text { responses to the } 8 \\
\text { knowledge items }\end{array}$ & \multicolumn{3}{c}{ No. (\%) of respondents } \\
\cline { 2 - 4 } & All (n=1013) & $\begin{array}{c}\text { Without CPR } \\
\text { training (n=799) }\end{array}$ & $\begin{array}{c}\text { With CPR } \\
\text { training (n=214) }\end{array}$ \\
\hline 0 & $323(31.9)$ & $303(37.9)$ & $20(9.3)$ \\
\hline 1 & $252(24.9)$ & $228(28.5)$ & $24(11.2)$ \\
\hline 2 & $178(17.6)$ & $148(18.5)$ & $30(14.0)$ \\
\hline 3 & $104(10.3)$ & $67(8.4)$ & $37(17.3)$ \\
\hline 5 & $71(7.0)$ & $35(4.4)$ & $36(16.8)$ \\
\hline 6 & $38(3.8)$ & $12(1.5)$ & $26(12.1)$ \\
\hline 7 & $23(2.3)$ & $2(0.3)$ & $21(9.8)$ \\
\hline 8 & $20(2.0)$ & $4(0.5)$ & $16(7.5)$ \\
\hline Abbrev) & $4(0.4)$ & 0 & $4(1.9)$ \\
\hline
\end{tabular}

Abbreviation: $\mathrm{CPR}=$ cardiopulmonary resuscitation

pay more attention to remind the trainees on the need for such reinstruction and updates.

The main reasons of taking CPR training were "job requirement" and "personal interest", which were similar to reasons given in a previous study from Ireland. ${ }^{18}$ Therefore, the workplace might be considered a preferred place to conduct CPR training in conjunction with government and nongovernment organisations; in Hong Kong, these include St John Ambulance, the Hong Kong Red Cross, and the Auxiliary Medical Services. In fact, promoting CPR training in workplace seems an important strategy, as $16 \%$ of trained respondents in this study had already received such training in their 
workplaces, and this was also in line with the results of a study by Jennings et al. ${ }^{18}$

In this study, most non-trained respondents would not consider receiving CPR training, giving the following reasons: "no time", "not necessary", or "not interested". Lack of time for CPR training is a common reason reported in different studies. ${ }^{11,23,24}$ To address this problem, self-instruction, such as via video or internet training, may be considered. Studies have shown that video self-instruction training was as good as traditional classroom training, ${ }^{25,26}$ which is not only cost-effective but also flexible compared to formal classroom training. In addition, as recommended by the $\mathrm{AHA},{ }^{8} \mathrm{CPR}$ training could be incorporated into general education in secondary schools. Several studies have investigated knowledge and attitude towards CPR training, its feasibility and the impact of CPR or life-supporting first-aid training in primary and secondary schools in various countries (Austria, Japan, and Norway) and reported a positive experience. ${ }^{27-29}$ Either as part of the regular curriculum, as mandatory courses, or as an elective extra-curricular activity, it could be beneficial to the students and the general public. By providing students with CPR training, the first part of the chain of survival in out-of-hospital cardiac arrest could be enhanced for future generations, and increase survival after sudden cardiac arrest. To successfully carry out such a health and education policy, the Hong Kong SAR Government can learn from other Asian countries like Japan and Singapore, which have already gained experience in CPR education for secondary schools.

Those with full-time jobs and with higher levels of education were more likely to attend CPR training, which corresponded with the results of previous studies. ${ }^{11,18}$ Not surprisingly $48 \%$ of respondents in the present study were required to attend their CPR training in connection with their jobs, while $18 \%$ believed that they were unable to learn as they were too old or their level of education was too low. Accordingly, this misunderstanding about CPR needs correcting, and certainly CPR training should be made available to those who are not employed. Community centres could be used as possible teaching venues to promote CPR, in conjunction with the Hong Kong SAR Government and other health care organisations (Hospital Authority, Hong Kong Red Cross, and St John Ambulance). These health-related organisations could play critical roles in publicising the importance of CPR, and provide accessible trainings for the public. Encouragingly, the Resuscitation Council of Hong Kong was established in 2012, and has the power to promote high standards of training and public awareness on resuscitation.

In this study, respondents with CPR training were more willing to perform it at home and in the street (under emergency situations), presumably as they had acquired enough knowledge and skills to generate confidence and courage. The powerful impact of CPR training on saving lives should never be underestimated. Although only $15 \%$ of the respondents without CPR training would like to save others' lives, nearly half of them (45\%) expressed willingness to perform CPR for their family members if needed. The intimate relationship among family members may be the motivation in such cases. According to the AHA, $80 \%$ of sudden cardiac arrests happen at home. ${ }^{7}$ Therefore, it makes sense to exploit intimate emotions to facilitate and publicise the CPR training, especially for those with vulnerable members in their family.

In this study, the overall level of CPR knowledge of the respondents was very low, with a median of one correct answer out of eight questions, which was in agreement with previous studies. ${ }^{11,20}$ Knowledge was particularly weak related to the compression-to-ventilation ratio and appropriate number of cardiac compressions per minute. This could be because $79 \%$ of the respondents had not received any CPR training, whereas $72 \%$ out of the 214 who had, recalled receiving it more than 2 years earlier and $51 \%$ had received it more than 5 years earlier. The AHA recommends its frequently revised CPR guidelines based on rigorous scientific evidence and the consensus opinions of experts. Using a compression-to-ventilation ratio of 30:2 during CPR for victims of all ages was a major update in $2005 .{ }^{30}$ In addition, the sequence of 'A-B-C' (Airway, Breathing, Chest compression) was changed to 'C-A-B' (Chest compression, Airway, Breathing) in the 2010 Guidelines. ${ }^{30}$ Therefore, knowledge about up-to-date guidelines is likely to be most rewarding.

This survey did not explore why people refused to perform CPR, which could be crucial for raising bystander CPR rates in Hong Kong. As indicated in one study from Japan, people had fear of contracting transmitted diseases through mouth-tomouth ventilations. ${ }^{13}$ Legal liability could be another concern. Therefore, public education and laws to protect CPR providers appear necessary, for which Good Samaritan laws need to be enacted. Certainly, the reasons why Hong Kong citizens opt not to undertake CPR warrant future surveys.

\section{Conclusions}

Knowledge of CPR in the Hong Kong public is still poor. The percentage of citizens that have had CPR training is relatively low. Unwillingness to perform CPR is particularly common, especially among those who have not received any CPR training. Government and non-government organisations need to promote educational activities and explore diverse approaches to reinforce and refresh the content of training. Government needs to increase public awareness of CPR and enact laws to protect 
bystanders undertaking CPR. Incorporating CPR training into the secondary school and college curricula has also been suggested.

\section{Declaration}

The authors declare that there is no conflict of interest.

\section{Acknowledgement}

The study was supported by the Nethersole School of Nursing, Cardiovascular and Acute Care Research Group Funding.

\section{Appendix}

Additional material related to this article can be found on the HKMJ website. Please go to <http:// www.hkmj.org>, search for the appropriate article, and click on Full Article in PDF or Full text in HTML following the title.

\section{References}

1. Travers AH, Rea TD, Bobrow BJ, et al. Part 4: CPR Overview, 2010 American Heart Association Guidelines for Cardiopulmonary Resuscitation and Emergency Cardiovascular Care. Circulation 2010;122(18 Suppl 3):S676-84.

2. Roger VL, Go AS, Lloyd-Jones DM, et al. Heart disease and stroke statistics - 2012 update: a report from the American Heart Association. Circulation 2012;125:e2-e220.

3. Nichol G, Thomas E, Callaway CW, et al. Regional variation in out-of-hospital cardiac arrest incidence and outcome. JAMA 2008;300:1423-31.

4. Chan PS, Jain R, Nallmothu BK, Berg RA, Susson C. Rapid response teams: a systematic review and meta-analysis. Arch Intern Med 2010;170:18-26.

5. Lee K. The Hong Kong College of Cardiology automated external defibrillator programme. The Hong Kong Medical Diary 2008;13:14-6.

6. Sasson C, Rogers MA, Dahl J, Kellermann AL. Predictors of survival from out-of-hospital cardiac arrest: a systematic review and meta-analysis. Circ Cardiovasc Qual Outcomes 2010;3:63-81.

7. Hazinski MF, Nolan JP, Billi JE, et al. Part 1: executive summary: 2010 international consensus on cardiopulmonary resuscitation and emergency cardiovascular care science with treatment recommendations. Circulation 2010;122(16 Suppl 2):s250-75.

8. Cave DM, Aufderheide TP, Beeson J, et al. Importance and implementation of training in cardiopulmonary resuscitation and automated external defibrillation in schools: a science advisory from the American Heart Association. Circulation 2011;123:691-706.

9. Wong TW, Yeung KC. Out-of-hospital cardiac arrest: two and a half years experience of an accident and emergency department in Hong Kong. J Accid Emerg Med J 1995;12:34-9.

10. Leung LP, Wong TW, Tong HK, Lo CB, Kan PG. Out-ofhospital cardiac arrest in Hong Kong. Prehosp Emerg Care 2001;5:308-11.

11. Cheung BM, Ho C, Kou KO, et al. Knowledge of cardiopulmonary resuscitation among the public in Hong
Kong: telephone questionnaire survey. Hong Kong Med J 2003;9:323-8.

12. Konstandions HD, Evangelos KI, Stamatis K, Thyresia S, Zacharenia AD. Community cardiopulmonary resuscitation training in Greece. Res Nurs Health 2008;31:165-71.

13. Taniguchi $\mathrm{T}$, Omi $\mathrm{W}$, Inaba $\mathrm{H}$. Attitudes toward the performance of bystander cardiopulmonary resuscitation in Japan. Resuscitation 2007;75:82-7.

14. American Heart Association. 2005 American Heart Association Guidelines for Cardiopulmonary Resuscitation and Emergency Cardiovascular Care. Part 3: overview of CPR. Circulation 2005;112:s12-8.

15. Hazinski MF, Gonzales L, O’Neill L, editors. BLS for healthcare providers: student manual. Dallas, TX: American Heart Association; 2006.

16. Hosmer DW, Lemeshow S. Applied logistic regression. 2nd ed. New York: John Wiley and Sons; 2000.

17. Larsen P, Pearson J, Galletly D. Knowledge and attitudes towards cardiopulmonary resuscitation in community. $\mathrm{N}$ Z Med J 2004;117:U870.

18. Jennings S, Hara TO, Cavanagh B, Bennett K. A national survey of prevalence of cardiopulmonary resuscitation training and knowledge of the emergency number in Ireland. Resuscitation 2009;80:1039-42.

19. Celenza T, Gennat HC, O'Brien D, Jacobs IG, Lynch DM, Jelinek GA. Community competence in cardiopulmonary resuscitation. Resuscitation 2002;55:157-65.

20. Rasmus A, Czekajlo MS. A national survey of the Polish population's cardiopulmonary resuscitation knowledge. Eur J Emerg Med 2000;7:39-43.

21. Sipsma K, Stubbs BA, Plorde M. Training rates and willingness to perform CPR in King Country, Washington: a community survey. Resuscitation 2011;82:564-7.

22. Berden HJ, Willems FF, Hendrick JM, Pijls NH, Knape JT. How frequently should basic cardiopulmonary resuscitation training be repeated to maintain adequate skills? BMJ 1993;306:1576-7.

23. Liu H, Clark AP. Cardiopulmonary resuscitation training for family members. Dimens Crit Care Nurs 2009;28:156-63.

24. Blewer AL, Leary M, Decker CS, et al. Cardiopulmonary resuscitation training of family members before hospital discharge using video self-instruction: a feasibility trial. J Hosp Med 2011;6:428-32.

25. Einspruch EL, Lynch B, Aufderheide TP, Nichol G, Becker L. Retention of CPR skills learned in a traditional AHA Heartsaver course versus 30-min video self-training: a controlled randomized study. Resuscitation 2007;74:476-86.

26. Chung CH, Siu AY, Po LL, Lam CY, Wong PC. Comparing the effectiveness of video self-instruction versus traditional classroom instruction targeted at cardiopulmonary resuscitation skills for laypersons: a prospective randomised controlled trial. Hong Kong Med J 2010;16:165-70.

27. Uray T, Lunaer A, Ochsenhofer A, et al. Feasibility of lifesupporting first-aid (LSFA) training as a mandatory subject in primary schools. Resuscitation 2003;59:211-20.

28. Hamasu S, Morimoto T, Kuramoto N, et al. Effects of BLS training on factors associated with attitude toward CPR in college students. Resuscitation 2009;80:359-64.

29. Kanstad BK, Nilsen SA, Fredriken K. CPR knowledge and attitude to performing bystander CPR among secondary school students in Norway. Resuscitation 2011;82:1053-9.

30. Field JM, Hazinski MF, Sayre MR, et al. Part 1: executive summary: 2010 American Heart Association Guidelines for Cardiopulmonary Resuscitation and Emergency Cardiovascular Care. Circulation 2010;112(18 Suppl 3): S640-56. 


\section{APPENDIX.}

\section{Cardiopulmonary Resuscitation Survey}

\section{$\ulcorner$ 心肺復蘇法」電話問卷調查}

1. 請問你今年幾多歲?

歲

2. 請問你的性別?
A. 男性
B. 女性

3. 請問你的教育程度：
A. 小學程度
B. 中學程度
C. 大學程度或以上
D. 其他 :

4. 你的職業 :
A. 文職
B. 專業
C. 退休人士
D. 待業
E. 家庭主婦
F. 學生
G. 其他 :

5. 你有沒有缺血性心臟病?
A. 有
B. 沒有

6. 請問你有沒有以下可以導致心臟病的健康因素呢?
i）膽固醇過高
ii) 高血脂
A. 有
B. 沒有
iii) 高血壓
A. 有
B. 沒有
iv）糖尿病
V) 過肥
A. 有
B. 沒有
vi)食煙
A. 有
B. 沒有
A. 有
B. 沒有
A. 有
B. 沒有

7. 你的家族裏面有沒有近親或家人患缺血性心臟病?
A. 有
B. 沒有

8. 你有沒有接受過「心肺復蘇法」的訓練呢?
A. 有
B. 沒有
如果有, 轉至第 9 條, 及跳過第13條
如果沒有, 轉至第13條

9. 你在哪兒接受訓練?
A. 香港聖約翰救護機構
B. 香港紅十字會
C. 明愛醫院急救培訓中心
D. 香港急症科醫學院
E. 其他機構或組織：

10. 你最近那次訓練是在甚麼時候?
A. 5年前或以上
B. 2至5年
C. 1至2年
D. 1 年內

11. 你為甚麼會參加「心肺復蘇法」的訓練呢?
A. 因為工作需要
B. 因為有興趣
C. 其他原因: 
12. 你曾否為別人（傷病者）進行「心肺復蘇法」（而不是訓練或實習）?

A. 有

B. 沒有

13. 請問你有沒有想過參加「心肺復蘇法」的訓練呢?
A. 有
B. 沒有
為什麼?
為什麼?

14. 如果你在街上見到有陌生人不省人事, 你會否為他做「心肺復蘇法」呢?
A. 會
為什麼?
B. 不會
為什麼?

15. 如果你在家中見到有家人不省人事, 你會否為他做 $「$ 心肺復蘇法」呢?
A. 會
B. 㞸會
為什麼?
為什麼?

16. 你如何斷定別人不省人事呢?
A. 用手大力拍打傷病者的胸膛, 檢查反應
B. 用手張開傷病者的眼睛, 檢查反應和意識
C. 輕搖傷病者的肩膊和叫喊他, 檢查反應和意識

17. 昏迷或不省人事的傷病者氣道阻塞或不能呼吸的主要原因是?
A. 舌頭後墜阻礙咽喉
B. 食物哽塞於咽喉
C. 頸部受創傷

18. 怎樣才令昏迷或不省人事的傷病者保持氣道暢通？
A. 將傷病者坐起來
B. 用按額托顎的手法
C. 將傷病者俯伏地上

19. 你如何為不省人事的傷病者檢查他有沒有呼吸呢?
A. 你將耳朵緊貼於他的胸膛上5-10秒的時間, 來聆聽他的呼吸聲
B. 你將兩隻手指放置他的鼻孔前約 5-10秒的時間來感覺他的呼吸
C. 用5-10秒的時間, 去觀察他的胸腔起伏, 聆聽他的呼吸聲, 用自己臉煩去感覺他的呼吸

20. 正確的心外壓及吹氣 (人工呼吸) 的比率是?
A. 心外壓及吹氣 (人工呼吸) 的比率是 30: 2
B. 心外壓及吹氣 (人工呼吸) 的比率是 20: 2
C. 心外壓及吹氣 (人工呼吸) 的比率是 10: 2

21. 怎樣為不省人事的傷病者檢查脈博?
A. 用食指和中指指頭感覺手腕的脈博約 5-10秒的時間
B. 用食指和中指指頭感覺喉核, 順着急救員的方向滑下至與鄰近肌肉帶中間, 用5-10秒的時間去感覺頸部大動 脈的脈博
C. 用手掌放於傷病者的胸膛約 5-10秒的時間來感覺脈博

22. 正確的心外壓速率是每分鐘多少次?
A. 速率：每分鐘最少一百次
B. 速率：每分鐘最少八十次
C. 速率：每分鐘最少六十次

23. 甚麼情況下才能為不省人事的傷病者使用自動體外心臟去顫器?
A. 沒有呼吸, 沒有脈博
B. 沒有呼吸, 沒有意識
C. 沒有意識, 沒有呼吸, 沒有脈博

24. 當傷病者的身體或胸腔浸於水中時, 急救員使用自動體外心臟去顫器需要特別注意或小心嗎?
A. 需要
B. 不需要

\section{End}

問卷完 